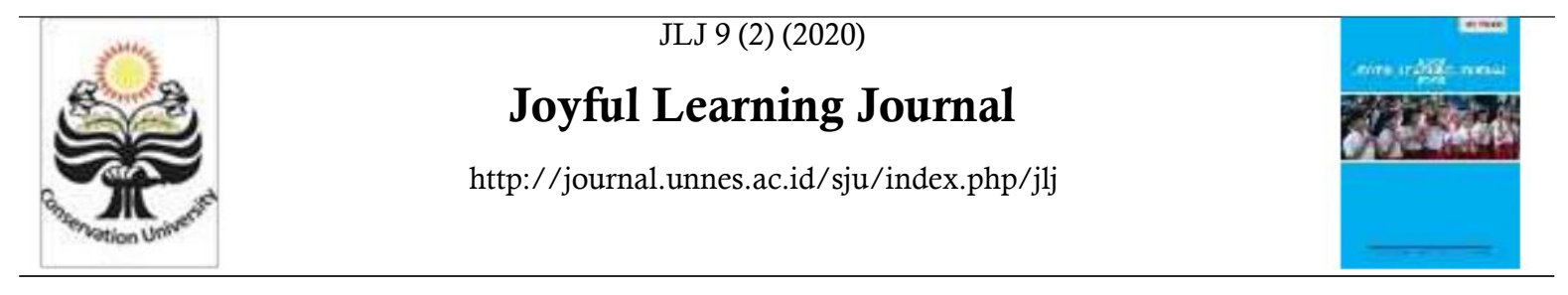

\title{
PENGEMBANGAN MULTIMEDIA INTERAKTIF AKSARA JAWA BERBASIS ADOBE FLASH UNTUK SISWA KELAS IV
}

\author{
Ema Nuryani ${ }^{\varpi}$, Arif Widagdo
}

Jurusan Pendidikan Guru Sekolah Dasar, Fakultas Ilmu Pendidikan, Universitas Negeri Semarang, Indonesia

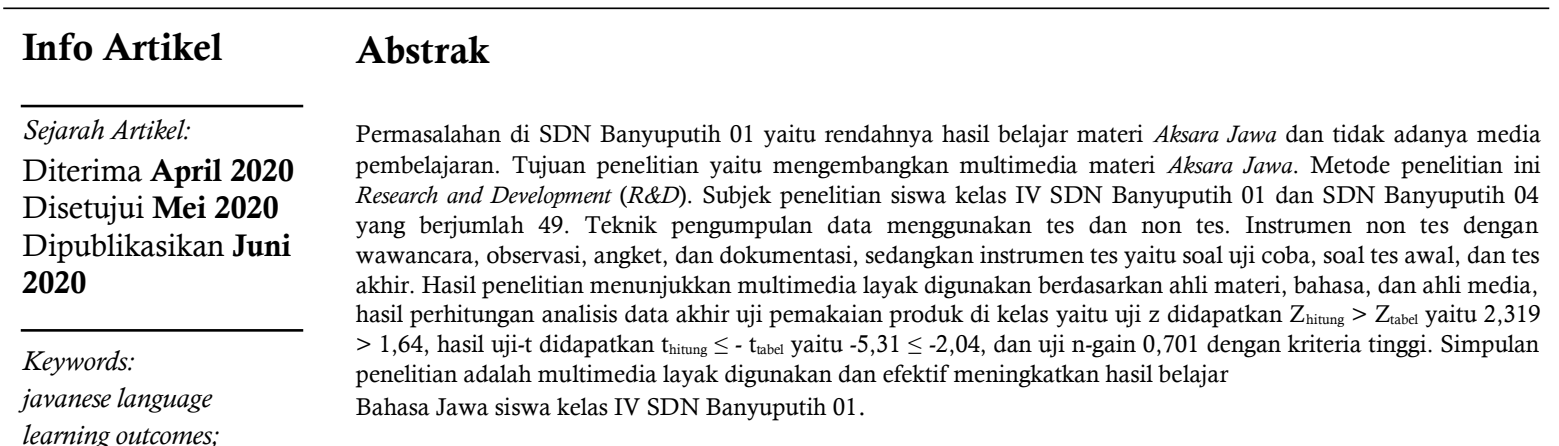

\begin{abstract}
The problems in Banyuputih State Elementary School 01 were based on the low cognitive learning outcomes in Javanese subjects precisely on (Javanese Alphabet) material and the absence of Javanese learning media. This research aimed to develop multimedia (Javanese alphabet) material. This metod of research was Research and Development (R\&D). The research subject was the students of grade IV Elementary School in Banyuputih 01 and Elementary School in Banyuputih 04 which amounted to 49 students. Data collection techniques are test and non-test. Non-test instruments used were interviews, observation, poll, and documentation, while the test instruments used are questions of trials, preliminary tests, and final tests. Eligibility assesment results demonstrate could be used based on material expert assessment, language amounted, and the media assessment. The results of the calculation of final data analysis in classes of the $z$ test obtained Zcount $>$ Ztable is $2.319>1.64$, the results of the $t$ test obtained tcount $\leq-$ ttable is $-5.31 \leq-2.04$ while the test results $n$-gain 0.701 with high criteria. The conclusion of this research was that adobe flash-based (Javanese alphabet) multimedia material was feasible to used and was effective in improving the learning outcomes of Javanese students in grade IV Banyuputih State Elementary School 01.
\end{abstract}

(C) 2020 Universitas Negeri Semarang

$\begin{array}{lc}\text { Alamat korespondensi: } & \text { ISSN 2252-6366 } \\ \text { Gamer Kulon RT 04 RW 02 Gamer Kota Pekalongan } & \\ \text { E-mail: emanuryani8@gmail.com } & \end{array}$




\section{PENDAHULUAN}

Berdasarkan Permendikbud No 67 tahun 2013 tentang kerangka dasar dan stuktur kurikulum SD, pada kurikulum 2013 dikembangkan pola pikir yaitu; (1) pembelajaran di pusatkan pada peserta didik, (2) pola pembelajaran interaktif guru, peserta didik, lingkungan dan masyarakat, (3) pola pembelajaran aktif, (4) pola belajar kelompok, (5) pembelajaran berbasis alat multimedia, (6) pola pembelajaran secara jejaring, (7) pembelajaran ilmu pengetahuan jamak, (8) Pola pembelajaran kritis sehingga Kompetensi Inti dan Kompetensi Dasar dapat dicapai pada diri peserta didik dalam pembelajaran seperti menurut Permendikbud No. 37 Tahun 2013 tentang tujuan kurikulum yang mencakup empat kompetensi, yaitu (1) kompetensi sikap spiritual; (2) sikap sosial; (3) pengetahuan; dan (4) keterampilan. Untuk mencapai kompetensi tersebut dapat melalui kegiatan intrakulikuler, ekstrakulikuler, dan kokulikuler. Selain untuk mencerdaskan generasi bangsa yang berpengetahuan, bermoral, dan berbudi pekerti, peran pendidikan juga sebagai sarana untuk melestarikan kebudayaan. Pendidikan sebagai sarana untuk mencegah dampak negatif dari globalisasi. Pendidikan yang berbasis muatan lokal merupakan hal penting yang harus di pelajari oleh diri peserta didik. Mengenai pendidikan muatan lokal di sekolah dasar sesuai dengan Peraturan Gubernur Jawa Tengah Nomor 57 tahun 2013 Bab III Pasal 5. Menurut peraturan tersebut, muatan Lokal Bahasa Jawa merupakan hal yang wajib dipelajari dan dilestarikan di Jawa Tengah diberbagai jenjang pendidikan termasuk SD.

Permasalahan yang ditemukan di SD Negeri Banyuputih 01, pada pembelajaran Bahasa Jawa di kelas IV, dari jumlah siswa 35 siswa kelas IV di SDN Banyuputih 01 terdapat 24 siswa yang mendapat nilai dibawah KKM 65 atau sejumlah $68,58 \%$ dan terdapat 11 siswa yang mendapat nilai diatas KKM atau sejumlah $31,42 \%$ saja yang mampu memenuhi KKM. Hal tersebut terjadi karena motivasi belajar siswa dalam pembelajaran Bahasa Jawa masih rendah dan hasil belajar Aksara Jawa juga masih rendah. Selain itu juga dipengaruhi oleh faktor pendukung pembelajaran dan profesionalisme guru, seperti media pembelajaran pada materi Aksara Jawa yang kurang inovatif dan interaktif.

Alternatif yang bisa dilakukan untuk meningkatkan hasil belajar Bahasa Jawa siswa adalah dengan mengembangkan multimedia. Hal ini ditegaskan oleh Daryanto (2016:7) Media pembelajaran adalah bagian dari sistem pembelajaran yang digunakan sebagai komponen komunikasi dan penyalur informasi. Dari penjelasan tersebut, penggunaan media pembelajaran sangat penting untuk untuk menyampaikan pesan yang berupa informasi kepada siswa. Sedangkan menurut Suryani, dkk (2018:196) penggunaan multimedia adalah alternatif untuk membentuk pembelajaran yang berkesan dengan melibatkan semua indera, waktu lebih efisien, dapat meningkatkan motivasi, dan mengenalkan teknologi sedini mungkin kepada siswa. Oleh sebab itu pengembangan multimedia berbasis Adobe Flash akan memudahkan siswa dalam belajar. Penelitian terdahulu yang relevan adalah penelitian oleh Sutarsih (2015) dengan judul "Pembelajaran Menulis Aksara Jawa Anak Kelas III Sekolah Dasar". Hasil penelitian yang dilakukan menunjukkan bahwa Kesulitan siswa dalam belajar menulis Aksara Jawa adalah mengenali bunyi dan menghapalkan bentuk Aksara Jawa. Penelitian yang dilakukan oleh Pribadi Prayoga dan Prasetyo Agung, (2016) dengan judul "Aplikasi Alat Bantu Belajar

Menulis Aksara Jawa Berbasis Multimedia untuk Kelas 3 Sekolah Dasar". Hasil penelitian dapat diketahui bahwa multimedia pembelajaran sebagai aplikasi yang digunakan dalam proses pembelajaran, multimedia sebagai penyalur pesan (pengetahuan, keterampilan dan sikap) serta dapat merangsang pilihan, perasaan, perhatian dan kemauan siswa sehingga proses belajar terjadi, bertujuan dan terkendali sehingga dengan penggunaan multimedia dapat membantu belajar menulis Aksara Jawa siswa. Penelitian lain dilakukan oleh Meylinda Frista (2016) dengan judul "Pengembangan Media Pembelajaran Keterampilan Berbicara dengan Program Adobe Flash untuk Siswa Kelas V SD" Hasil penelitian diketahui bahwa Adobe Flash dipilih sebagai media karena program ini dapat menghasilkan animasi bergerak yang digabungkan dengan suara dan tulisan, sehingga lebih menarik minat siswa dalam pembelajaran. Selain itu, Adobe Flash juga sesuai dengan perkembangan kognisi siswa kelas V SD"

Jurnal penelitian internasional oleh Beasley (2019) dengan judul "The effects of international email and Skype interactions on computer-mediated communication perceptions and attitudes and intercultural competence in Taiwanese students". Hasil penelitian manfaat dari media berbasis computer dapat membantu peserta menciptakan perancah sosial dan lingkungan, meningkatkan motivasi dan keterlibatan dalam pembelajaran yang efektif melalui kolaborasi dalam penelitian ini berupa pretest dan posttest media sinkron dan asinkon Pardimin, dkk (2018) dengan judul "Developing Multimedia Application Model for basic Mathematics Learning". Hasil penelitian multimedia untuk merancang berbagai gambar animasi, meningkatkan minat, memudahlan siswa mengimplementasikan pembelajaran berbasis multimedia, mempengaruhi hasil belajar, memudahkan guru menyampaikan materi, dan memperkenalkan teknologi untuk siswa dan guru itu sendiri. Penelitian Irlidiya (2015), multimedia 
pembelajaran Interaktif adalah kombinasi dua media input atau output data. Media ini dapat berupa audio, animasi, video, teks dan gambar dengan mengintegrasikan tautan yang memungkinkan pengguna berinteraksi, membuat dan menyampaikan.

Tujuan penelitian ini adalah untuk mengembangkan multimedia yang dapat meningkatkan hasil belajar Bahasa Jawa kelas IV SD Negeri Banyuputih 01, menguji kelayakan multimedia materi Aksara Jawa berbasis adobe flash untuk meningkatkan hasil belajar siswa pada mata pelajaran Bahasa Jawa kelas IV SD Negeri Banyuputih 01, menguji keefektifan multimedia materi Aksara Jawa berbasis adobe flash untuk meningkatkan hasil belajar siswa pada mata pelajaran Bahasa Jawa kelas IV SD Negeri Banyuputih 01.

\section{METODE PENELITIAN}

Jenis penelitian ini adalah Research and Development (R\&D). Penelitian ini menggunakan model penelitian pengembangan dengan sepuluh langkah pelaksanaan mengacu pada teori Borg dan Gall (Sugiyono 2015:409). Kemudian peneliti hanya menggunakan 9 dari 10 langkah yaitu 1) potensi dan masalah; 2) mengumpulkan informasi; 3) pengembangan desain produk; 4) validasi desain; 5) revisi desain; 6) uji coba produk; 7) revisi produk; 8) uji coba pemakaian; 9) revisi produk. Sumber data penelitian ini berasal wawancara dengan guru kelas IV di SDN Banyuputih 01, dokumen hasil belajar siswa, dan dokumen pembelajaran. Subyek dalam penelitian ini adalah siswa, guru, ahli materi, media, ahli bahasa, dan peneliti.

Variabel bebas dalam penelitian ini adalah multimedia materi Aksara Jawa berbasis adobe flash. Variabel terikat dalam penelitian ini adalah hasil belajar Bahasa Jawa. Teknik tes dari observasi, wawancara, angket, dan dokumentasi. Teknis analisis data yang digunakan yaitu analisis data produk, analisis data awal, dan analisis data akhir (uji t, uji gain).

\section{HASIL PENELITIAN DAN PEMBAHASAN}

\section{Analisis Potensi dan Masalah}

Tahapan potensi dan masalah, dilakukan melalui wawancara guru, observasi, dan studi dokumen berupa hasil PAS di SDN Banyuputih 1. Dari hasil PAS kelas IV mata pelajaran Bahasa Jawa, didapatkan bahwa dari 35 siswa diketahui 24 siswa atau 68,58\% masih dibawah KKM (Kriteria Ketuntasan Minimal) 65. Berdasarkan hasil wawancara, observasi, dan dokumentasi hasil belajar PAS menunjukkan perlunya pengembangan multimedia di kelas IV SDN Banyuputih 01. Selanjutnya, penelitian fokus di dua SD yaitu SDN Banyuputih 01 dan SDN Banyuputih 04. Dipilihnya dua SD tersebut berdasarkan hasil uji normalitas dan uji homogenitas.

\section{Pengumpulan Informasi \\ Pengumpulan informasi dilaksanakan} tangal 23 Desember 2019 sampai tanggal 11 Februari 2020 dan dilakukan di SDN Banyuputih 01. Kemudian informasi diolah dalam bentuk perencanaan produk yang diharapkan dapat menjadi solusi masalah. Hal ini didukung oleh penelitian yang dilakukan oleh Priyanto (2016). Penelitian ini bertujuan untuk mengetahui prosedur pengembangan terdiri dari tiga tahap meliputi; 1) pengumpulan informasi kondisi awal pembelajaran, studi lapangan, analisis data dan analisis kebutuhan media pembelajaran, 2) Perancangan terdiri dari penyusunan model faktual dan merancang model desain, 3) Pengembangan terdiri dari tahap validasi, uji coba dan revisi media pembelajaran.

Dari angket yang diberikan kepada 49 siswa, disimpulkan bahwa siswa membutuhkan multimedia untuk dapat memahami materi Aksara Jawa dan meningkatkan motivasi belajar siswa. Sedangkan hasil angket analisis kebutuhan guru dapat disimpulkan bahwa guru memerlukan multimedia materi Aksara Jawa untuk memudahkan menyampaikan materi.

\section{Desain Produk}

Desain multimedia digunakan untuk mengembangkan multimedia. Pembuatan multimedia menggunakan Corel Draw dan Adobe Flash. Halaman multimedia, kompetensi dasar dan indikator yang akan dicapai, tujuan pembelajaran, lembar kerja siswa berupa latihan-latihan soal evaluasi, dan kuis. Hal tersebu sejalan dengan penelitian Bachtiar (2018). Penelitian diketahui bahwa hasil tahapan pengembangan aplikasi multimedia terdiri dari dua antara lain; (1) Praproduksi yaitu peneliti menganalisis kebutuhan dengan kuesioner dan studi literature. Kemudian, mendesain game, suara, editing gambar, animasi, dan video (2) Produksi yaitu membuat flowchart, storyboard, menyiapkan bahan, dan hyperlink.. dari hasil penilaian ahli dapat disimpulkan bahwa multimedia yang dikembangkan mendapatkan kategori sangat layak untuk digunakan pada pembelajaran Bahasa Jawa materi Aksara Jawa.

\section{Revisi Desain \\ Desain multimedia diperbaiki untuk meningkatkan kelayakan multimedia berdasarkan saran perbaikan dari dosen, ahli media, ahli materi, dan ahli bahasa. Hal yang perlu diperbaiki meliputi perbaikan teks, perbaikan indikator, perbaikan tujuan pembelajaran, perbaikan bahasa, daftar pustaka, kuis, soal evaluasi, dan perbaikan isi materi. Hal ini didukung oleh Suyantiningsih (2016), pada penelitian diketahui bahwa multimedia yang}


dihasilkan divalidasi oleh ahli media dan ahli materi agar menghasilkan media yang layak. Validasi materi dilakukan untuk mengetahui kedalaman dan kekinian materi. Sedangkan ahli media dilakukan untuk mengetahui apakah multimedia memenuhi kualifikasi media yang layak.

\section{Validasi Desain}

Penilaian kelayakan produk multimedia dilakukan oleh ahli materi, ahli Bahasa, dan ahli media. Uji kelayakan digunakan untuk mengetahui apakah produk yang dikembangkan layak atau tidak layak untuk digunakan dalam pembelajaran Bahasa Jawa kelas IV materi Aksara Jawa. Hal tersebut didukung penelitian oleh Chulkamdi dan Purnomo (2016). Prosedur penelitian yaitu; analisis kebutuhan, perancangan desain, implementasi desain, pengujian, validasi ahli, revisi media, uji kelayakan, dan produk. Dosen ahli materi dan ahli Bahasa untuk uji kelayakan multimedia adalah Didik Supriadi, S.Pd.,M.Pd. Beliau adalah dosen Pendidikan Bahasa Jawa di jurusan Pendidikan Bahasa Jawa FBS UNNES. Sedangkan untuk dosen ahli media adalah Novi Setyasto, S.Pd.,M.Pd. Beliau adalah Pendidikan Guru Sekolah Dasar, FIP UNNES. Berikut Hasil penilaian multimedia berdasarkan penilaian Ahli.

Tabel 1. Hasil Penilaian Validasi Desain Ahli Materi, Bahasa, dan Media

\begin{tabular}{|c|c|c|}
\hline \multirow{2}{*}{ Validasi Desain } & Nilai & Kriteria \\
\hline & Persentase & \\
\hline Validasi isi materi & $84 \%$ & $\begin{array}{l}\text { Sangat } \\
\text { Layak }\end{array}$ \\
\hline $\begin{array}{l}\text { Validasi bahasa } \\
\text { yang digunakan }\end{array}$ & $86 \%$ & $\begin{array}{l}\text { Sangat } \\
\text { Layak }\end{array}$ \\
\hline Validasi media & $88,75 \%$ & $\begin{array}{l}\text { Sangat } \\
\text { Layak }\end{array}$ \\
\hline
\end{tabular}

\section{Analisis Data}

\section{Uji Coba Produk Kelompok Kecil}

Tahap uji coba produk kelompok kecil untuk mengetahui respon awal serta kinerja multimedia ketika digunakan dalam pembelajaran. Subjek penelitian siswa kelas IV SDN Banyuputih 04 yang berjumlah 19 siswa. Berdasarkan hasil ujicoba pada kelompok kecil ini, pada kelas pretest diperoleh zhitung sebesar 7,5498 dan ztabel dengan taraf signifikansi 0,05 sebesar 1,64, artinya ketuntasan belajar sebelum menggunakan Multimedia Interaktif Aksara Jawa $<75 \%$. Pada kelas posttest diperoleh $\mathrm{z}$ hitung sebesar 1,9868 uji proporsi satu pihak dengan taraf signifikansi 0,05 yaitu 1,64. Hasil perhitungan $\mathrm{Uji}$ perbedaan rata-rata dihitung menggunakan rumus paired sampel t-test bahwa thitung $\leq$ - ttabel yaitu $-4,22 \leq-2,09$. Simpulan bahwa $\mathrm{H} 0$ ditolak dan $\mu \mathrm{B}<0$, artinya perbedaan nilai pretest dan posttest kurang dari nol. Jadi, nilai pretest kurang dari nilai posttest. Sedangkan hasil uji n-gain menunjukkan peningkatan hasil sebesar 0,701 dengan kriteria tinggi.

\section{Revisi Produk}

Dari angket analisis tanggapan guru, multimedia mendapatkan saran pertahankan materi dengan langkah saintifik dan pada materi sandhangan terdapat kata yang perlu diperbaiki.

\section{Spesifikasi Multimedia}

Multimedia yang dikembangkan memiliki keunggulan dibandingkan dengan media pembelajaran berupa gambar, yaitu multimedia dilengkapi penyajian materi cara menulis dan membaca Aksara Jawa sehingga memudahkan siswa dalam mempelajari materi Aksara Jawa dan dilengkapi dengan soal evaluasi serta kuis yang terdapat kunci jawaban di halaman akhir. Berikut tabel perbedaan kegiatan pembelajaran siswa menggunakan powerpoint dan menggunakan multimedia. Hal tersebut didukung oleh penelitian Anjarwati, dkk (2016) dengan judul "Improving Learning Outcomes by Developing Instructional Media-Based Adobe Flash Professional CS 5.5 on Principles of Business Subject". Hasil penelitian dapat diketahui tampilan awal berisi pengantar berisi teks, gambar /logo dan efek pembuka yang mengarah ke menu utama media. Selanjutnya, layar memperlihatkan menu utama: rumah, menu SK / KD, tentang (tujuan dan indikator), bahan, evaluasi, glosarium, instruksi, profil, dan referensi.

Tabel 2. Perbedaan Pembelajaran Siswa Menggunakan Powerpoint dan Multimedia.

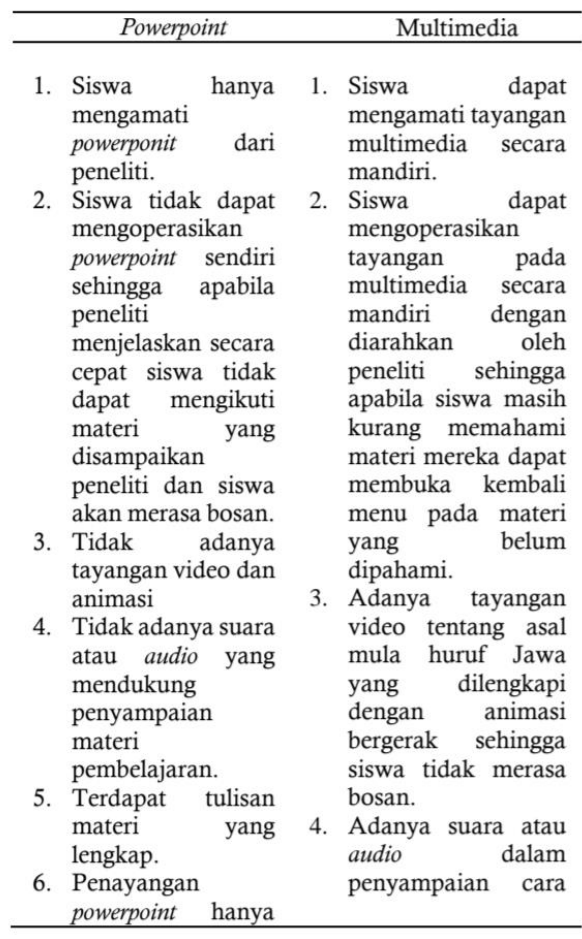




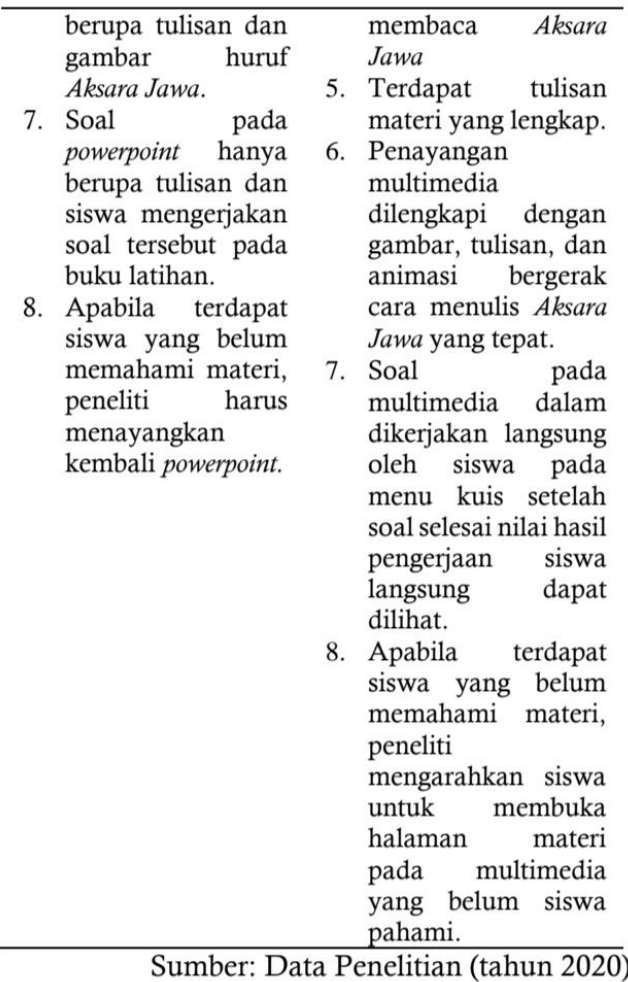

\section{Uji Pemakaian Produk Kelompok Besar}

Uji coba produk skala besar dilakukan kepada 30 siswa di SDN Banyuputih 01. Uji coba dilakukan di kelompok besar bertujuan untuk menguji keefektifan multimedia terhadap hasil belajar Bahasa Jawa pada materi Aksara Jawa siswa kelas IV. Hasil dari Uji Coba Produk Skala Besar pada kelas pretest diperoleh zhitung sebesar $-9,4868$ dan ztabel dengan taraf signifikansi 0,05 sebesar 1,64 , artinya bahwa kriteria ketuntasan belajar sebelum menggunakan Multimedia Interaktif Aksara Jawa kurang dari $75 \%$. Pada kelas posttest diperoleh $\mathrm{z}$ hitung sebesar 2,319 uji proporsi satu pihak dengan taraf signifikansi 0,05 yaitu 1,64. Jadi, pada kelas posttest Zhitung $>$ Ztabel artinya bahwa kriteria ketuntasan belajar setelah menggunakan Multimedia Interaktif Aksara Jawa lebih dari $75 \%$. Hasil perhitungan Uji perbedaan rata-rata dihitung menggunakan rumus paired sampel t-test observasi berpasangan sehingga diperoleh data bahwa thitung $\leq-$ ttabel yaitu $-5,31 \leq-2,04$. Maka dapat disimpulkan bahwa H0 ditolak dan $\mu \mathrm{B}<0$, artinya perbedaan nilai pretest dan posttest kurang dari nol. Hasil yang didapatkan pada uji coba produk skala besar diketahui terdapat peningkatan hasil sebesar 0,701 dengan kriteria tinggi.

\section{SIMPULAN}

Berdasarkan penelitian pengembangan dan pembahasan dapat disimpulkan bahwa pengembangan multimedia sesuai kebutuhan guru dan siswa. Multimedia yang dikembangkan sangat layak untuk digunakan berdasarkan penilaian ahli materi, bahasa, dan ahli media. Keefektifan multimedia dilakukan dengan analisis data akhir. Pada kelas kelompok besar z hitung sebesar -9,4868 hasil pretest dan $\mathrm{z}$ hitung 2,319 untuk posttest dengan taraf signifikansi 0,05 yaitu 1,64 . Pada kelas posttest Zhitung $\geq$ Ztabel artinya ketuntasan belajar setelah menggunakan Multimedia $>$ $75 \%$. Sedangkan hasil perhitungan uji t pada kelas kelompok besar menunjukkan bahwa thitung $=-5,31$ dan ttabel $=-2,04$. Dengan hasil tersebut thitung $\leq$ ttabel dan $\mu \mathrm{B}<0$. Pada uji coba produk skala besar adanya perbedaan ratarata hasil belajar siswa sebelum dan setelah menggunakan Multimedia Interaktif, pada uji N-Gain diketahui peningkatan sebesar 0.701 dengan kriteria tinggi.

\section{UCAPAN TERIMA KASIH}

Penulis mengucapkan terima kasih kepada Allah SWT, yang selalu memberikan kelancaran dan kemudahan, kepada kedua orang tua atas dukungan dan doa yang diberikan, dosen pembimbing Arif Widagdo, S.Pd., M.Pd., Drs. Sutaryono, M.Pd. selaku mitra bestari I, Drs. Sukardi, M.Pd, S., selaku mitra bestari II, Arif Widagdo, S.Pd., M.Pd., yang telah memberikan bimbingan dalam menyusun manuskrip ini.

\section{DAFTAR PUSTAKA}

Adittia, Arya. (2017). Penggunaan Media Pembelajaran Audio Visual untuk Meningkatkan Hasil Belajar IPS pada Siswa Kelas IV SD. Jurnal Mimbar Sekolah Dasar. 4 (1): 17

Ahmadi, Farid, dkk. (2017). Pengembangan Media Edukasi "Multimedia Indonesian Culture" (Mic) sebagai Penguatan Pendidikan Karakter Siswa Sekolah Dasar.

Jurnal Penelitian Pendidikan. 34(2). Anjarwati, Devi., Winarno, Agung., \& Churiyah, Madziatul. 2016. Improving Learning Outcomes by Developing Instructional MediaBased Adobe Flash Professional CS 5.5 on Principles of Business Subject. IOSR Journal of Research \& Method in Education (IOSRJRME). 6(5).

Bakhtiar, Faisal Azmi. 2018. Pengembangan Aplikasi Berbasis Multimedia pada Pembelajaran Tematik Kelas III Sekolah Dasar. Jurnal Mimbar Sekolah Dasar. 5 (1).

Beasley, R.E. 2019. The effects of international email and Skype interactions on computer-mediated communication perceptions and attitudes and intercultural competence in Taiwanese students. Australasian Journal of Educational Technology. 35(1): 105. 
Irlidiya, dkk. 2015. The Development of Interactive Multimedia for First-grade Beginning Readers of Elementary School: An Innovative Learning Approach. Journal of Language Teaching and Research. $6(3)$.

Meylinda,F., Yuwana, S., \& Sukartiningsih, W. 2016. Pengembangan Media Pembelajaran Keterampilan Berbicara dengan Program Adobe flash Untuk Siswa Kelas V SD. Jurnal Kajian Pendidikan dan Hasil Penelitian. 2 (3).

Pardimin, dkk. 2018. Developing Multimedia Application Model for basic Mathematics Learning. Jour of $A d v$ Research in Dynamical \& Control Systems. 10(14).

Peraturan Gubernur Jawa Tengah Nomor 57 tahun 2013 Bab III.

Peraturan Menteri Pendidikan dan Kebudayaan Nomor 37 Tahun 2013 Tentang Kompetensi Inti dan Kompetensi Dasar Pelajaran pada Kurikulum 2013 pada Pendidikan Dasar dan Pendidikan Menengah.

Peraturan Menteri Pendidikan dan Kebudayaan Nomor 67 Tahun 2013 Tentang
Kerangka Dasar dan Struktur Kurikulum Sekolah dasar/ Madrasah Ibtidaiyah.

Pribadi, Prayoga. \& Prasetyo, Agung. 2016. Aplikasi Alat Bantu Belajar Menulis Aksara Jawa Berbasis Multimedia untuk Kelas 3 Sekolah Dasar. Jurnal IT CIDA. 2 (1): 33 .

Sugiyono. 2015. Metode Penelitian dan Pengembangan Research and development. Bandung: Alfabeta

Sugiyono. 2016. Metode Penelitian dan Pengembangan Research and development. Bandung: Alfabeta

Suryani, N., Setiawan, A., \& Putria A. 2018. Media Pembelajaran Inovatif dan pengembangannya. Bandung: Rosda.

Sutarsih. 2015. Pembelajaran Menulis Aksara Jawa Anak Kelas III Sekolah Dasar. Jurnal Aksara. 27(1): 65-72.

Suyantiningsih., Munawaroh, I \& Rahmadona, S. 2016. Pengembangan Multimedia Pembelajaran Berbasis Scientific Approach Terintegrasi Nilai Karakter. Jurnal Kependidikan. 46(1) 